\title{
BMJ Open Potential determinants of vitamin D in Finnish adults: a cross-sectional study from the Northern Finland birth cohort 1966
}

\author{
Saranya Palaniswamy, ${ }^{1,2}$ Elina Hyppönen, ${ }^{3,4}$ Dylan M Williams, ${ }^{5}$ Jari Jokelainen, ${ }^{2,6}$ \\ Estelle Lowry, ${ }^{1,2}$ Sirkka Keinänen-Kiukaanniemi, ${ }^{2,6}$ Karl-Heinz Herzig, ${ }^{1,7,8,9}$ \\ Marjo-Riitta Järvelin, ${ }^{1,2,6,10,11}$ Sylvain Sebert ${ }^{1,2,12}$
}

To cite: Palaniswamy S, Hyppönen E, Williams DM, et al. Potential determinants of vitamin $D$ in Finnish adults: a cross-sectional study from the Northern Finland birth cohort 1966. BMJ Open 2017;7:e013161. doi:10.1136/bmjopen-2016013161

- Prepublication history and additional material is available. To view please visit the journal (http://dx.doi.org/ 10.1136/bmjopen-2016013161)

Received 23 June 2016 Revised 2 January 2017 Accepted 5 January 2017

CrossMark

For numbered affiliations see end of article.

Correspondence to Dr Saranya Palaniswamy; saranya.palaniswamy@oulu.fi

\section{ABSTRACT}

Objective: Evidence from randomised controlled trials suggests that vitamin D may reduce multimorbidity, but very few studies have investigated specific determinants of vitamin D2 and D3 (two isoforms of 25-hydroxyvitamin D). The aim of the study was to investigate the determinants of vitamin D2 and D3 and to identify the risk factors associated with

hypovitaminosis $\mathrm{D}$.

Design: Cross-sectional study.

Setting: Northern Finland Birth Cohort 1966.

Participants: 2374 male and 2384 female participants with data on serum $25(\mathrm{OH}) \mathrm{D}_{2}$ and $25(\mathrm{OH}) \mathrm{D}_{3}$ concentrations measured at 31 years of age (1997), together with comprehensive measures of daylight, anthropometric, social, lifestyle and contraceptive cofactors.

Methods: We assessed a wide range of potential determinants prior to a nationwide fortification programme introduced in Finland. The determinants of $25(\mathrm{OH}) \mathrm{D}_{2}, 25(\mathrm{OH}) \mathrm{D}_{3}$ and $25(\mathrm{OH}) \mathrm{D}$ concentrations were analysed by linear regression and risk factors for being in lower tertile of $25(\mathrm{OH}) \mathrm{D}$ concentration by ordinal logistic regression.

Results: At the time of sampling, $72 \%$ of the participants were vitamin $D$ sufficient $(\geq 50 \mathrm{nmol} / \mathrm{L})$. Low sunlight exposure period (vs high) was associated positively with $25(\mathrm{OH}) \mathrm{D}_{2}$ and negatively with $25(\mathrm{OH}) \mathrm{D}_{3}$ concentrations. Use of oral contraceptives (vs nonusers) was associated with an increase of $0.17 \mathrm{nmol} / \mathrm{L}$ $(95 \% \mathrm{Cl} 0.08$ to 0.27$)$ and $0.48 \mathrm{nmol} / \mathrm{L}(95 \% \mathrm{Cl} 0.41$ to 0.56 ) in $25(\mathrm{OH}) \mathrm{D}_{2}$ and $25(\mathrm{OH}) \mathrm{D}_{3}$ concentrations. Sex, season, latitude, alcohol consumption and physical activity were the factors most strongly associated with 25(OH)D concentration. Risk factors for low vitamin $D$ status were low sunlight exposure defined by time of sampling, residing in northern latitudes, obesity, higher waist circumference, low physical activity and unhealthy diet.

Conclusions: We demonstrate some differential associations of environmental and lifestyle factors with $25(\mathrm{OH}) \mathrm{D}_{2}$ and $25(\mathrm{OH}) \mathrm{D}_{3}$ raising important questions related to personalised healthcare. Future strategies could implement lifestyle modification and
Strengths and limitations of this study

- Data were from a large homogeneous Northern Finnish Birth Cohort (latitude $\geq 65^{\circ} \mathrm{N}$ ) and included information on several determinants of $25(\mathrm{OH}) \mathrm{D}_{2}$ and $25(\mathrm{OH}) \mathrm{D}_{3}$ in young adults.

- The sample was collected in Finland before the implementation of national policy on fortification of milk and margarine with vitamin D.

- This is the first study to report the influence of oral contraceptive pills on $25(\mathrm{OH}) \mathrm{D}_{2}$ and $25(\mathrm{OH})$ $\mathrm{D}_{3}$ concentrations.

- The finding offers an independent replication of the differential associations of seasonality with serum $25(\mathrm{OH}) \mathrm{D}_{2}$ and $25(\mathrm{OH}) \mathrm{D}_{3}$ concentrations, as previously observed in British children supporting evidence for different biological pathways regulating vitamin $\mathrm{D} 2$ and $\mathrm{D} 3$ status.

- Limitations of the study include lack of a more precise measure of UV-B exposure, information on whether study participants were taking vitamin D supplementation, detailed dietary index and information on outdoor and indoor physical activity which could help account for residual confounders.

supplementation to improve vitamin D2 and D3 status, accounting for seasonal, lifestyle, metabolic and endocrine status.

\section{INTRODUCTION}

Serum 25-hydroxyvitamin D $(25(\mathrm{OH}) \mathrm{D})$, the circulating biomarker of vitamin $\mathrm{D}$ status, is found to be associated with multiple pathological conditions. ${ }^{1-4}$ There is growing interest in understanding the causal role of vitamin $\mathrm{D}$ in the aetiology of chronic metabolic diseases including obesity, ${ }^{1}{ }^{2}$ type 2 diabetes $^{3}$ and mortality. ${ }^{4}$ Vitamin D is classified as a pro-hormone which exists in circulation 
in two major forms of $25(\mathrm{OH}) \mathrm{D}: 25(\mathrm{OH}) \mathrm{D}_{2}$ (ergocalciferol) and $25(\mathrm{OH}) \mathrm{D}_{3}$ (also known as cholecalciferol). ${ }^{56}$ Serum $25(\mathrm{OH}) \mathrm{D}_{2}$ is obtained only from plant-derived dietary sources, fortification or supplementation. ${ }^{5}{ }^{7}$ In contrast, $25(\mathrm{OH}) \mathrm{D}_{3}$ is predominantly obtained from sunlight exposure and smaller quantities from dietary sources such as fatty fish, fortified milk products and supplements. ${ }^{5}{ }^{6}$ In Finland, the milk products and spreadable fats are fortified with $25(\mathrm{OH}) \mathrm{D}_{3} .{ }^{8}$ The current fortification contains $25(\mathrm{OH}) \mathrm{D}_{3}$ due to somewhat lower biopotency of $25(\mathrm{OH}) \mathrm{D}_{2}$ that requests further understanding. ${ }^{8}$ Vitamin $\mathrm{D}$ status is determined by measuring $25(\mathrm{OH}) \mathrm{D},{ }^{7}$ which reflects the combined intake of vitamins $25(\mathrm{OH}) \mathrm{D}_{2}$ and $25(\mathrm{OH}) \mathrm{D}_{3}$ and subcutaneous synthesis during the past 3-4 weeks. ${ }^{5} 910$

There is limited knowledge about the factors associated with each isoform that may have differential environmental determinants. ${ }^{10}$ Total $25(\mathrm{OH}) \mathrm{D}$ and the relative proportions of $25(\mathrm{OH}) \mathrm{D}_{2}$ and $25(\mathrm{OH}) \mathrm{D}_{3}$ are suggested to reflect a number of health and lifestyle factors that might be sex specific. ${ }^{11}{ }^{12}$ In young adults, lifestyle and body composition differ between men and women. ${ }^{12} 13$ As to whether the differential composition of the body between sexes, as well as other endocrine factors, will be reflected by differences in the $25(\mathrm{OH}) \mathrm{D}$ concentration and the $25(\mathrm{OH}) \mathrm{D}_{2}$ and $25(\mathrm{OH}) \mathrm{D}_{3}$ components is yet unknown. ${ }^{12} 13$ There are no previous comprehensive studies examining the factors associated with $25(\mathrm{OH}) \mathrm{D}_{2}$ and $25(\mathrm{OH}) \mathrm{D}_{3}$ concentrations in Finland. This limits the availability of inferences that could help to identify people at risk of vitamin D deficiency, and improved fortification policies to meet the requirements of those living at northern latitudes. ${ }^{8} 14$

We examined here factors associated with $25(\mathrm{OH}) \mathrm{D}_{2}$, $25(\mathrm{OH}) \mathrm{D}_{3}$ and total $25(\mathrm{OH}) \mathrm{D}$ concentrations in Finnish adults aged 31 years prior to the implementation of a nationwide supplementation of vitamin $D$ via fortification of milk products and margarine in 2002. ${ }^{8} 14$

\section{METHODS}

\section{Study population}

We analysed data on participants from the Northern Finland Birth Cohort 1966 (NFBC1966) which has previously been described in detail. ${ }^{15}{ }^{16}$ In brief, all women who were pregnant, residing in Northern Finland (provinces of Oulu and Lapland) with expected dates of delivery between 1 January and 31 December,1966 were targeted for enrolment in the study. Over $96 \%$ of eligible women participated. This comprised of 12055 mothers and 12058 live born children. The children were followed up at regular intervals from birth onwards. In 1997, when participants were aged 31 years, all cohort participants with known addresses in the provinces of Oulu and Lapland $\left(65^{\circ} \mathrm{N}\right.$ to $\left.70^{\circ} \mathrm{N}\right)$ and in Helsinki $\left(60^{\circ} \mathrm{N}\right)$ area were sent a postal questionnaire and invited to a clinical examination which also included, a fasted blood sample. ${ }^{17}$ A total of $\mathrm{N}=4758$ individuals of white European origin were included in the study as shown in online supplementary figure S1. All participants gave written informed consent. The procedures follow the 1964 Helsinki declaration and its later amendments or comparable ethical standards. The present study includes individuals with a complete set of data on variables of interest, as detailed below.

\section{Outcome variables}

25(OH)D measurement

Serum $25(\mathrm{OH}) \mathrm{D}_{2}$ and $25(\mathrm{OH}) \mathrm{D}_{3}$ were measured by liquid chromatography tandem mass spectrometry and the detailed assay procedure is published elsewhere. ${ }^{18}$ Participants with $25(\mathrm{OH}) \mathrm{D}_{2}$ values under the detectable limit were assigned a value of $1.25 \mathrm{nmol} / \mathrm{L}{ }^{18}$ Total 25 $(\mathrm{OH}) \mathrm{D}$ is obtained as the actual sum of $\mathrm{D} 2+\mathrm{D} 3$ without $25(\mathrm{OH}) \mathrm{D}_{2}$ low value assignment. Consequently, in the tables, total $25(\mathrm{OH}) \mathrm{D}$ may differ slightly from exact sum of D2 and D3. Vitamin D sufficiency criteria were defined according to the Institute of Medicine (IOM) guidelines as $\leq 30 \mathrm{nmol} / \mathrm{L}$ (risk/deficiency), 30 $50 \mathrm{nmol} / \mathrm{L}$ (risk/insufficiency) and $\geq 50 \mathrm{nmol} / \mathrm{L}$ (sufficient). ${ }^{19}$

\section{Explanatory factors}

The season of participant attendance at the clinical assessment was categorised according to the Finnish Meteorological Institute standard as high sunlight (summer (1 June-30 August) autumn (1 September-31 October)) and low sunlight season (winter (1 November-31 March) and spring (1 April-31 May) )..$^{20}$ This definition aims to assess the impact of natural high and low vitamin D level periods throughout the calendar year. The residence of the participants at age 31 years was collected from the population register office. They were categorised as residing in Helsinki $\left(60^{\circ} \mathrm{N}\right)$; the city of Oulu $\left(65^{\circ} \mathrm{N}\right)$ and elsewhere in northernmost provinces of Oulu and Lapland $\left(>65^{\circ} \mathrm{N}\right)$. In Helsinki, blood samples were collected only during winter in contrast to all year round in other provinces, due to the feasibility of data collection and were excluded in multivariable analyses. Height $(\mathrm{cm})$ and weight $(\mathrm{kg})$ were measured in barefoot and loose clothing by well-trained nurses. Body Mass Index (BMI) $\left(\mathrm{kg} / \mathrm{m}^{2}\right)$ was calculated and categorised according to the WHO $1998 .{ }^{21}$ Waist circumference $(\mathrm{cm})$ was categorised as elevated when it was $\geq 94 \mathrm{~cm}$ in men and $\geq 80 \mathrm{~cm}$ in women. ${ }^{22}$

Categorisation of following lifestyle variables was based on the responses in the postal questionnaire. Current smoking was categorised as non-smoker, former/occasional or active smoker. Alcohol consumption during the 6 months prior to the questionnaire was calculated as grams per day ( $\mathrm{g} /$ day) and has been described elsewhere. ${ }^{23}$ It was further categorised according to WHO sex-specific classification as abstainer, low-risk drinker ( $\leq 20$ and $\leq 40 \mathrm{~g} /$ day for women and men, respectively) or at-risk drinker $(>20$ and $>40 \mathrm{~g} /$ day for women and men, respectively). ${ }^{24}$ The frequency of computer use 
during leisure time was categorised as never, no more than once per week, on 2-5 days per week or on more than 5 days per week. The reported frequency and duration of leisure time and brisk physical activity were used to calculate the metabolic equivalent of task (MET) scores in hours per week, and these were ordered into quartiles. An intensity value of 3 METs is considered as light physical activity, and 5 METs as brisk physical activity. ${ }^{25}$ Diet score was calculated based on the consumption of various food in the previous 6 months and was reported on a structured six-point scale (from never/ $<$ once per month to several times per day) and has been described previously. ${ }^{23}$ The food frequency question included 32 products categorised under grain products, milk products, vegetables, meat, fruits and others (chocolates, sweets and packaged meals). An unhealthy diet included daily or frequent consumption of red meat and less frequent consumption of rye or crisp bread, berries or fruit, salads and vegetables. The score ranged from $0-5$ and was categorised as healthy diet ( $<3$ points) and unhealthy diet (4-5 points). ${ }^{23}$ Current use of contraception by women was categorised as no contraception use, other methods of contraception (hormone intrauterine device (IUD), copper IUD, chemical contraception) or oral contraceptive pill (OCP) ${ }^{26}$ Socioeconomic position (SEP) was categorised as I and II (professional), III (skilled worker), IV (unskilled worker), V (farmer) and VI (others-pensioner, student, long-term unemployed or not defined). The exclusion criteria consisted of participants with non-fasting blood samples, pregnant women, no consent for use of data and persons whose information was missing on one or more variables of interest.

\section{Statistical analyses}

All statistical analyses were performed using SAS V.9.4 (SAS Institute, Cary, NC, USA). The variables were assessed for normality and $\log$ transformed where relevant. Mean differences between sexes for continuous variables were measured by independent samples t-test and analysis of variance; and Pearson $\chi^{2}$ test for categorical variables. We performed univariable linear regression analysis to explore the association between explanatory variables and serum $25(\mathrm{OH}) \mathrm{D}_{2}, 25(\mathrm{OH}) \mathrm{D}_{3}$ and total $25(\mathrm{OH}) \mathrm{D}$ concentrations. We $\log$ transformed $25(\mathrm{OH}) \mathrm{D}_{2}, 25(\mathrm{OH}) \mathrm{D}_{3}$ and $25(\mathrm{OH}) \mathrm{D}$, and expressed these on standardised scales (z-scores). To examine whether sex was an effect modifier of associations, an interaction term (sex $\times$ explanatory variable) was additionally included in univariable analyses. We conducted multivariable analyses aiming to examine mutually adjusted associations of different exposures with $25(\mathrm{OH})$ $\mathrm{D}_{2}, 25(\mathrm{OH}) \mathrm{D}_{3}$ and $25(\mathrm{OH}) \mathrm{D}$ measures, namely season of blood sampling (low and high sunlight period), latitude, BMI, waist circumference, SEP, smoking status, alcohol consumption, leisure time computer use, physical activity, diet score and contraception status. In addition, we examined serum $25(\mathrm{OH}) \mathrm{D}_{2}, 25(\mathrm{OH}) \mathrm{D}_{3}$ and 25
$(\mathrm{OH}) \mathrm{D}$ concentrations by excluding women using OCPs.

Following examination of the determinants associated with $25(\mathrm{OH}) \mathrm{D}_{2}, 25(\mathrm{OH}) \mathrm{D}_{3}$ and $25(\mathrm{OH}) \mathrm{D}$ concentrations, we performed multinomial ordinal logistic regression analysis to assess the risk factors associated with being in the lower tertile (reference: tertile III) of vitamin D. Owing to equivocal definitions of cut-off values for vitamin $\mathrm{D}$ status in the general population, we categorised the analysis sample into tertiles of $25(\mathrm{OH})$ D. Statistical significance was set at global $\mathrm{p}<0.05$ using two-tailed test.

\section{RESULTS}

The characteristics of the study population at age 31 years are summarised in table 1. According to Institute of Medicine (IOM) criteria for vitamin D sufficiency, $3.3 \%$ were deficient, $24.2 \%$ were insufficient and $71.5 \%$ were sufficient. A total of $3.0 \%$ of men and $3.5 \%$ of women were deficient. Serum D2 concentrations were lower in men when compared with women. However, the mean serum D3 and total $25(\mathrm{OH}) \mathrm{D}$ concentrations tended to be higher in men than in women, although the difference was not statistically significant. Though, the difference became more pronounced after excluding women using OCPs. There were no interactions observed by sex with any explanatory variables ( $p$ for interactions $>0.05$, data not shown).

\section{Risk factors associated with lower vitamin D status according to tertile distribution}

Characteristics of the study population across the tertiles of serum $25(\mathrm{OH}) \mathrm{D}$ concentration are summarised in table 2 (total), online supplementary tables S1 and S2 (men and women, respectively). Unadjusted and adjusted ordinal logistic regression analyses for the odds of being in the lower tertiles of $25(\mathrm{OH}) \mathrm{D}$ compared with the highest are shown in online supplementary table S3. The mutually adjusted model shows the risk of being in lower tertile of $25(\mathrm{OH}) \mathrm{D}$ was increased in individuals whose blood samples were collected during low sunlight months, living in higher latitudes, having elevated waist circumference and unhealthy diet. Figure 1 illustrates the mutually adjusted analyses with OR estimates for the impact of daylight, anthropometric, social and lifestyle risk factors for being in vitamin D tertile I (low) compared with tertile III (high). In sex-stratified analysis, women using OCPs had reduced odds of being in the tertile I (low) of $25(\mathrm{OH}) \mathrm{D}$. The mean vitamin $\mathrm{D}$ concentration was $\sim 10 \%$ higher in OCP users (vs non-users).

\section{Factors associated with serum $25(\mathrm{OH}) \mathrm{D}_{2}, 25(\mathrm{OH}) \mathrm{D}_{3}$ and 25(OH)D concentrations}

Univariable and multivariable associations of daylight, anthropometric, social and lifestyle factors with $25(\mathrm{OH})$ $\mathrm{D}_{2}, 25(\mathrm{OH}) \mathrm{D}_{3}$ and $25(\mathrm{OH}) \mathrm{D}$ in the total population are shown in table 3, online supplementary tables S4 and S5 
Table 1 Characteristics of the study population*

\begin{tabular}{|c|c|c|c|c|c|c|c|}
\hline \multirow[b]{2}{*}{ Sample size (n) } & \multicolumn{2}{|l|}{$\begin{array}{l}\text { Total } \\
4758\end{array}$} & \multicolumn{2}{|l|}{$\begin{array}{l}\text { Male } \\
2374\end{array}$} & \multicolumn{2}{|c|}{$\begin{array}{l}\text { Female } \\
2384 \\
\end{array}$} & \multirow[b]{2}{*}{ p Value } \\
\hline & $\begin{array}{l}\mathrm{n} \text { or } \\
\text { mean }\end{array}$ & $\begin{array}{l}\% \text { or } \\
95 \% \mathrm{Cl}\end{array}$ & $\begin{array}{l}\text { or } \\
\text { mean }\end{array}$ & $\begin{array}{l}\% \text { or } \\
95 \% \mathrm{Cl}\end{array}$ & $\begin{array}{l}\mathrm{n} \text { or } \\
\text { mean }\end{array}$ & $\%$ or $95 \% \mathrm{Cl}$ & \\
\hline \multicolumn{8}{|l|}{ Daylight } \\
\hline \multicolumn{8}{|l|}{ Season of blood samplingt ( $\mathrm{n} \%$ ) } \\
\hline High sunlight & 2953 & 62.1 & 1501 & 63.2 & 1452 & 60.9 & 0.09 \\
\hline Low sunlight & 1805 & 37.9 & 873 & 36.8 & 932 & 39.1 & \\
\hline \multicolumn{8}{|l|}{ Latitude $\neq$ (n \%) } \\
\hline $65^{\circ} \mathrm{N}$ & 891 & 28.7 & 460 & 29.3 & 431 & 28.1 & 0.58 \\
\hline$>65^{\circ} \mathrm{N}$ & 3105 & 71.3 & 1571 & 70.7 & 1534 & 71.9 & \\
\hline \multicolumn{8}{|l|}{ Anthropometry } \\
\hline BMI $\left(\mathrm{kg} / \mathrm{m}^{2}\right)$ (mean, $\left.95 \% \mathrm{Cl}\right)$ & 24.7 & 24.6 to 24.8 & 25.2 & 25.1 to 25.3 & 24.1 & 23.9 to 24.3 & $<0.01$ \\
\hline Waist circumference $(\mathrm{cm})$ (mean, $95 \% \mathrm{Cl}$ ) & 83.8 & 83.5 to 84.2 & 88.9 & 88.5 to 89.3 & 78.8 & 78.3 to 79.2 & $<0.01$ \\
\hline \multicolumn{8}{|l|}{ Socioeconomic position: ( $\mathrm{n} \%$ ) } \\
\hline I+ll (Professional) & 1134 & 23.8 & 653 & 27.5 & 481 & 20.2 & $<0.01$ \\
\hline III (Skilled worker) & 1483 & 31.2 & 433 & 18.2 & 1050 & 44.0 & \\
\hline IV (Unskilled worker) & 1228 & 25.8 & 856 & 36.1 & 372 & 15.6 & \\
\hline $\mathrm{V}$ (Farmer) & 165 & 3.5 & 111 & 4.7 & 54 & 2.3 & \\
\hline VI (Other) & 748 & 15.7 & 321 & 13.5 & 427 & 17.9 & \\
\hline \multicolumn{8}{|l|}{ Lifestyle } \\
\hline \multicolumn{8}{|l|}{ Smoking ( $\mathrm{n} \%)$} \\
\hline Non-smoker & 2128 & 44.7 & 952 & 40.1 & 1176 & 49.4 & $<0.01$ \\
\hline Former/occasional smoker & 1214 & 25.5 & 600 & 25.3 & 614 & 25.7 & \\
\hline Active smoker & 1416 & 29.8 & 822 & 34.6 & 594 & 24.9 & \\
\hline \multicolumn{8}{|l|}{ Alcohol consumption (g/day) (n \%) } \\
\hline Abstainer & 426 & 8.95 & 191 & 8.1 & 235 & 9.9 & $<0.01$ \\
\hline Low-risk drinker & 4053 & 85.18 & 2026 & 85.3 & 2027 & 85.0 & \\
\hline At-risk drinker & 279 & 5.86 & 157 & 6.6 & 122 & 5.1 & \\
\hline \multicolumn{8}{|l|}{ Leisure time computer use ( $\mathrm{n} \%$ ) } \\
\hline Never & 1708 & 35.9 & 852 & 35.9 & 856 & 35.9 & $<0.01$ \\
\hline No more than once per week & 691 & 14.5 & 312 & 13.1 & 379 & 15.9 & \\
\hline On 2 to 5 days per week & 1419 & 29.8 & 656 & 27.6 & 763 & 32.0 & \\
\hline On more than 5 days per week & 940 & 19.8 & 554 & 23.4 & 386 & 16.2 & \\
\hline $\begin{array}{l}\text { Physical activity (MET hours/week) } \\
\text { (mean, } 95 \% \mathrm{Cl} \text { ) }\end{array}$ & 15.0 & 14.6 to 15.4 & 14.9 & 14.4 to 15.6 & 15.0 & 14.5 to 15.6 & $<0.01$ \\
\hline \multicolumn{8}{|l|}{ Diet score $(n \%)$} \\
\hline $0-1$ & 1461 & 30.71 & 453 & 19.1 & 1008 & 42.3 & $<0.01$ \\
\hline $2-3$ & 2739 & 57.57 & 1531 & 64.5 & 1208 & 50.6 & \\
\hline $4-5$ & 558 & 11.73 & 390 & 16.4 & 168 & 7.1 & \\
\hline \multicolumn{8}{|l|}{ Contraception status§ ( $\mathrm{n} \%$ ) } \\
\hline No contraception & & & & & 1154 & 49.1 & \\
\hline Other kinds of contraception & & & & & 591 & 25.1 & \\
\hline Oral contraceptive pills (OCP) & & & & & 607 & 25.8 & \\
\hline \multicolumn{8}{|l|}{ Vitamin D status (mean, $95 \% \mathrm{Cl}$ ) } \\
\hline Serum total $25(\mathrm{OH}) \mathrm{D} \rrbracket$ & 68.4 & 67.6 to 69.2 & 68.9 & 67.7 to 70.1 & 67.9 & 66.7 to 68.9 & 0.78 \\
\hline Serum $25(\mathrm{OH}) \mathrm{D}_{3}$ & 64.8 & 63.9 to 65.6 & 65.6 & 64.4 to 66.7 & 64.0 & 62.8 to 65.1 & 0.45 \\
\hline Serum $25(\mathrm{OH}) \mathrm{D}_{2}$ & 4.2 & 3.9 to 4.3 & 3.9 & 3.6 to 4.2 & 4.4 & 4.1 to 4.7 & $<0.01$ \\
\hline \multicolumn{8}{|c|}{ Vitamin D status without $\mathrm{OCP}^{\star *}$ (mean, $95 \% \mathrm{Cl}$ ) } \\
\hline Serum total $25(\mathrm{OH}) \mathrm{D} \rrbracket$ & 67.0 & 66.2 to 67.9 & 68.9 & 67.7 to 70.1 & 64.6 & 63.3 to 65.8 & $<0.01$ \\
\hline Serum $25(\mathrm{OH}) \mathrm{D}_{3}$ & 63.6 & 62.8 to 64.5 & 65.6 & 64.4 to 66.7 & 60.9 & 59.8 to 62.2 & $<0.01$ \\
\hline Serum $25(\mathrm{OH}) \mathrm{D}_{2}$ & 4.0 & 3.8 to 4.2 & 3.9 & 3.6 to 4.2 & 4.2 & 3.9 to 4.5 & 0.05 \\
\hline
\end{tabular}

Values are presented as mean, $95 \%$ Cls or number (\%).

*p Value was calculated using independent samples $t$-test for normally distributed variables and Pearson's $\chi^{2}$ test for categorical variables. †The season of blood sampling were categorised as high sunlight (summer (1 June-30 August), autumn (1 September-31 October)) and low sunlight (winter (1 November-31 March) and spring (1 April-31 May)).

‡Data included only on samples taken during all seasons from Oulu city and other provinces of Oulu and Lapland. Data not included on $\mathrm{N}=343$ in men and $\mathrm{N}=419$ in women with samples taken during winter months from Helsinki region.

§Data available on $\mathrm{N}=2352$ individuals ( $\mathrm{N}=32$ missing with contraception status in women).

ๆSerum total 25(OH)D may differ slightly from the actual sum of D2 and D3 because of amendment of undetectable D2 values (see methods).

${ }^{* *}$ Data on $\mathrm{N}=607$ using oral contraceptives excluded.

$\mathrm{BMI}$, body mass index; MET, metabolic equivalent of task of physical activity; $25(\mathrm{OH}) \mathrm{D}, 25$-hydroxyvitamin $\mathrm{D} ; 25(\mathrm{OH}) \mathrm{D}_{2}$, ergocalciferol; 25 $(\mathrm{OH}) \mathrm{D}_{3}$, cholecalciferol. 
Table 2 The characteristic of all Northern Finland Birth Cohort (NFBC) 1966 participants $(\mathrm{N}=4758)$ in the present study at 31 years by serum 25-hydroxyvitamin D tertiles* (I= the lowest tertile; III= the highest tertile)

\begin{tabular}{|c|c|c|c|c|c|c|c|}
\hline \multirow{2}{*}{$\begin{array}{l}\text { Tertile of serum } 25(\mathrm{OH}) \mathrm{D} \dagger \\
\mathrm{N}\end{array}$} & \multicolumn{2}{|l|}{$\begin{array}{l}\text { I } \\
1592\end{array}$} & \multicolumn{2}{|l|}{$\begin{array}{l}\text { II } \\
1589\end{array}$} & \multicolumn{2}{|l|}{$\begin{array}{l}\text { III } \\
1577\end{array}$} & \multirow[b]{2}{*}{ p Value } \\
\hline & $\mathrm{n}$ or mean & $\%$ or $95 \% \mathrm{Cl}$ & $\mathrm{n}$ or mean & $\%$ or $95 \% \mathrm{Cl}$ & n or mean & $\%$ or $95 \% \mathrm{Cl}$ & \\
\hline \multicolumn{8}{|l|}{ Sex $n \%$} \\
\hline Males & 782 & 32.9 & 800 & 33.7 & 792 & 33.4 & \multirow[t]{2}{*}{0.75} \\
\hline Females & 810 & 33.9 & 789 & 33.2 & 785 & 32.9 & \\
\hline \multicolumn{8}{|l|}{ Environmental factors } \\
\hline \multicolumn{8}{|l|}{ Season of blood drawn $\ddagger \mathrm{n} \%$} \\
\hline High sunlight & 566 & 19.2 & 1012 & 34.3 & 1375 & 46.5 & \multirow[t]{2}{*}{$<0.000$} \\
\hline Low sunlight & 1026 & 56.9 & 577 & 31.9 & 202 & 11.2 & \\
\hline \multicolumn{8}{|l|}{ Latitude§ n \% } \\
\hline $65^{\circ} \mathrm{N}$ & 210 & 23.6 & 305 & 34.2 & 376 & 42.2 & \multirow[t]{2}{*}{0.0006} \\
\hline$>65^{\circ} \mathrm{N}$ & 923 & 29.7 & 1042 & 33.6 & 1140 & 36.7 & \\
\hline \multicolumn{8}{|l|}{ Anthropometry } \\
\hline Body mass index $\left(\mathrm{kg} / \mathrm{m}^{2}\right)$ mean $95 \% \mathrm{Cl}$ & 24.8 & 24.6 to 25.0 & 24.8 & 24.6 to 24.9 & 24.4 & 24.2 to 24.6 & 0.017 \\
\hline Waist circumference $(\mathrm{cm})$ mean $95 \% \mathrm{Cl}$ & 84.6 & 83.9 to 85.2 & 84.0 & 83.4 to 84.6 & 82.9 & 82.3 to 83.4 & 0.0003 \\
\hline \multicolumn{8}{|l|}{ Socioeconomic position $\mathrm{n} \%$} \\
\hline I+II (Professional) & 421 & 37.2 & 374 & 32.9 & 339 & 29.9 & \multirow[t]{5}{*}{0.0046} \\
\hline III (Skilled worker) & 501 & 33.8 & 503 & 33.9 & 479 & 32.3 & \\
\hline IV (Unskilled worker) & 386 & 31.4 & 427 & 34.8 & 415 & 33.8 & \\
\hline $\mathrm{V}$ (Farmer) & 60 & 36.4 & 49 & 29.7 & 56 & 33.9 & \\
\hline VI (Other) & 224 & 29.9 & 236 & 31.6 & 288 & 38.5 & \\
\hline \multicolumn{8}{|l|}{ Lifestyle factors } \\
\hline \multicolumn{8}{|l|}{ Smoking $n \%$} \\
\hline Non-smoker & 742 & 34.9 & 686 & 32.2 & 700 & 32.9 & \multirow[t]{3}{*}{0.055} \\
\hline Former/occasional smoker & 366 & 30.2 & 438 & 36.1 & 410 & 33.7 & \\
\hline Active smoker & 484 & 34.2 & 465 & 32.9 & 467 & 32.9 & \\
\hline \multicolumn{8}{|l|}{ Alcohol consumption (g/day) n \% } \\
\hline Abstainer & 165 & 38.7 & 146 & 34.3 & 115 & 27.0 & \multirow[t]{3}{*}{0.053} \\
\hline Low risk drinker & 1335 & 32.9 & 1349 & 33.3 & 1369 & 33.8 & \\
\hline At-risk drinker & 92 & 32.9 & 94 & 33.7 & 93 & 33.4 & \\
\hline \multicolumn{8}{|l|}{ Leisure time computer use $\mathrm{n} \%$} \\
\hline Never & 537 & 31.4 & 599 & 35.1 & 572 & 33.5 & 0.0012 \\
\hline No more than once per week & 208 & 30.1 & 234 & 33.9 & 249 & 36.0 & \\
\hline On 2 to 5 days per week & 487 & 34.3 & 447 & 31.5 & 485 & 34.2 & \\
\hline On more than 5 days per week & 360 & 38.3 & 309 & 32.9 & 271 & 28.8 & \\
\hline Quartile of physical activity (MET hours $p$ & jer week) $n$ \% & & & & & & \\
\hline QI: 0.0-3.79 & 444 & 36.6 & 394 & 32.5 & 376 & 30.9 & $<0.0001$ \\
\hline QII: 3.80-11.29 & 403 & 33.9 & 421 & 35.4 & 365 & 30.7 & \\
\hline QIII: $11.30-21.99$ & 415 & 34.5 & 397 & 33.0 & 391 & 32.5 & \\
\hline QIV: >22.0 & 330 & 28.7 & 377 & 32.7 & 445 & 38.6 & \\
\hline Diet score $n \%$ & & & & & & & \\
\hline $0-1$ & 478 & 32.7 & 477 & 32.7 & 506 & 34.6 & 0.26 \\
\hline $2-3$ & 912 & 33.3 & 920 & 33.6 & 907 & 33.1 & \\
\hline $4-5$ & 202 & 36.2 & 192 & 34.4 & 164 & 29.4 & \\
\hline Females only & & & & & & & \\
\hline Contraception n \% & & & & & & & \\
\hline No contraception & 441 & 38.2 & 401 & 34.8 & 312 & 27.0 & $<0.001$ \\
\hline Other kinds of contraception & 216 & 36.6 & 187 & 31.6 & 188 & 31.8 & \\
\hline Oral contraceptive pills & 140 & 23.1 & 190 & 31.3 & 277 & 45.6 & \\
\hline
\end{tabular}

The values are expressed as mean and $95 \%$ Cls; numbers and \%.

*Differences between males and females were tested with ANOVA for normally distributed variables and Pearson's $\chi^{2}$ test for categorical variables.

†Mean $(95 \% \mathrm{Cl})$ of 25-hydroxyvitamin D tertiles for all were 41.50 (41.11 to 41.89$), 63.87$ (63.55 to 64.19$)$ and 100.01 (98.81 to 101.22 ). Serum total 25(OH)D may differ slightly from the actual sum of D2 and D3 because of amendment of undetectable D2 values (see methods). ¥The season of blood sampling were categorised as high sunlight (summer (1 June-30 August), autumn (1 September-31 October)) and low sunlight (winter (1 November-31 March) and spring (1 April-31 May)).

$\S$ Data included only on samples taken during all seasons from Oulu city and other provinces of Oulu and Lapland. Data not included on $\mathrm{N}=343$ in men and $\mathrm{N}=419$ in women with samples taken during winter months from Helsinki region.

MET, metabolic equivalent of task of physical activity; $25(\mathrm{OH}) \mathrm{D}, 25$-hydroxyvitamin $\mathrm{D}$; 


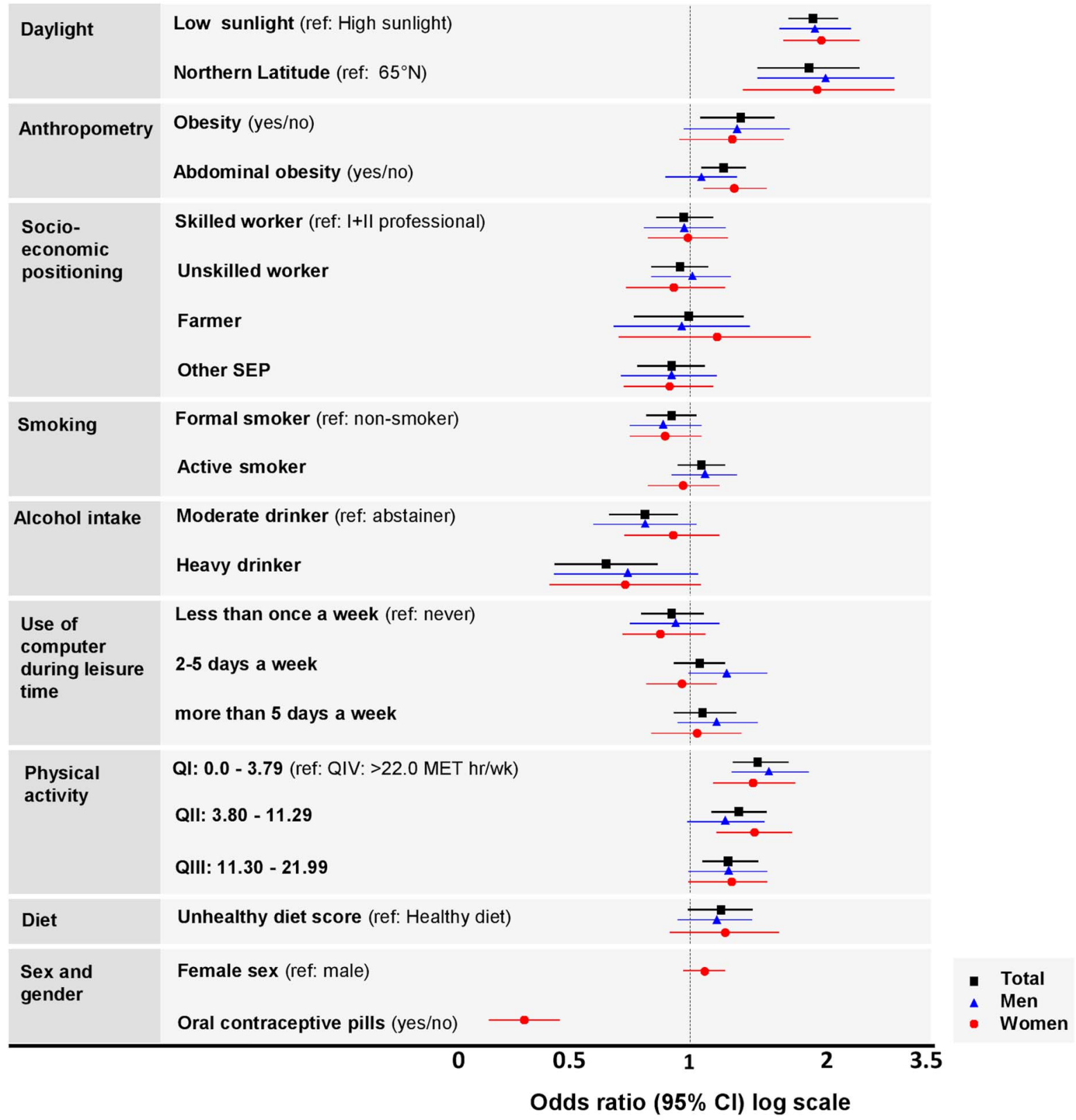

Figure 1 Forest plots showing the risk factors associated with low vitamin D status based on tertile distribution in the total population and by sex. Associations from mutually adjusted ordinal logistic regression ORs (on log scale) show the risk of being in the lower vitamin $\mathrm{D}$ tertile.

(men and women, respectively). The factors associated with $25(\mathrm{OH}) \mathrm{D}_{2}$ and $25(\mathrm{OH}) \mathrm{D}_{3}$ were sex, season of blood sampling, latitude, obesity, waist circumference and physical activity. Unhealthy diet and active smoking were univariably associated with lower $25(\mathrm{OH}) \mathrm{D}_{2}$ concentrations; and SEP was associated univariably with lower $25(\mathrm{OH}) \mathrm{D}_{3}$ concentrations.

In multivariable analyses, sex was associated with serum $25(\mathrm{OH}) \mathrm{D}_{2}$ and $25(\mathrm{OH}) \mathrm{D}_{3}$ concentrations. Men had $0.5 \mathrm{nmol} / \mathrm{L}$ lower $25(\mathrm{OH}) \mathrm{D}_{2}$ but $1.6 \mathrm{nmol} / \mathrm{L}$ higher $25(\mathrm{OH}) \mathrm{D}_{3}$ than women. When women using oral contraceptives were excluded from the analysis, the association between sex and $25(\mathrm{OH}) \mathrm{D}_{2}$ concentration was attenuated $(\beta=0.06 ; 95 \%$ CI -0.002 to 0.13$)$.
Conversely, the sex difference still persisted for $25(\mathrm{OH})$ $\mathrm{D}_{3}$ concentrations $(\beta=-0.21 ; 95 \%$ CI -0.26 to -0.15$)$, that is, women having lower concentrations. Low sunlight exposure period (vs high) at sampling associated with higher concentrations of $25(\mathrm{OH}) \mathrm{D}_{2}$ but lower concentrations of $25(\mathrm{OH}) \mathrm{D}_{3}$. Alcohol abstainers were associated with lower $25(\mathrm{OH}) \mathrm{D}_{3}$ concentrations than any other level of drinker. In addition, unhealthy diet score and leisure time computer use were associated with lower $25(\mathrm{OH}) \mathrm{D}_{3}$ concentrations.

In sex-stratified analyses, the associations were in the same direction and of similar magnitude with $25(\mathrm{OH})$ $\mathrm{D}_{2}$ and $25(\mathrm{OH}) \mathrm{D}_{3}$ concentrations. Female OCP users (vs non-users) had greater serum $25(\mathrm{OH}) \mathrm{D}_{2}$ and 25 
Table 3 Major factors associated with serum $25(\mathrm{OH}) \mathrm{D}_{2}$ (vitamin $\left.\mathrm{D} 2\right), 25(\mathrm{OH}) \mathrm{D}_{3}$ (vitamin $\mathrm{D} 3$ ) and total $25(\mathrm{OH}) \mathrm{D}$ (vitamin $\left.\mathrm{D}\right) \mathrm{nmol} / \mathrm{L}$ concentrations assessed by univariable and multiple linear regression analysis, total $(\mathrm{N}=4758)^{*}$

\begin{tabular}{|c|c|c|c|c|c|c|c|c|c|c|c|c|}
\hline \multirow{3}{*}{$\begin{array}{l}\text { Explanatory } \\
\text { variables }\end{array}$} & \multicolumn{4}{|c|}{ Serum $25(\mathrm{OH}) \mathrm{D}_{2}, \mathrm{nmol} / \mathrm{L} \dagger$} & \multicolumn{4}{|c|}{ Serum $25(\mathrm{OH}) \mathrm{D}_{3}, \mathrm{nmol} / \mathrm{L} \dagger$} & \multicolumn{4}{|c|}{ Serum 25(OH)D, nmol/L† } \\
\hline & \multicolumn{2}{|c|}{ Univariable } & \multicolumn{2}{|c|}{ Multivariableł } & \multicolumn{2}{|c|}{ Univariable } & \multicolumn{2}{|c|}{ Multivariable } & \multicolumn{2}{|c|}{ Univariable } & \multicolumn{2}{|c|}{ Multivariableł } \\
\hline & $\mathbf{B}$ & $95 \% \mathrm{Cl}$ & $\bar{\beta}$ & $95 \% \mathrm{Cl}$ & $\bar{\beta}$ & $95 \% \mathrm{Cl}$ & $\bar{\beta}$ & $95 \% \mathrm{Cl}$ & $\bar{\beta}$ & $95 \% \mathrm{Cl}$ & $\bar{\beta}$ & $95 \% \mathrm{Cl}$ \\
\hline \multicolumn{13}{|l|}{ Sex (reference: males) } \\
\hline $\begin{array}{l}\text { Females } \\
\text { Global } p \text { value }\end{array}$ & 0.10 & $\begin{array}{l}0.04 \text { to } 0.16 \\
0.0008\end{array}$ & 0.12 & $\begin{array}{l}0.06 \text { to } 0.18 \\
0.0001\end{array}$ & -0.06 & $\begin{array}{l}-0.12 \text { to }-0.003 \\
0.038\end{array}$ & -0.09 & $\begin{array}{l}-0.14 \text { to }-0.04 \\
0.0005\end{array}$ & -0.04 & $\begin{array}{l}-0.09 \text { to } 0.02 \\
0.21\end{array}$ & -0.06 & $\begin{array}{l}-0.12 \text { to }-0.01 \\
0.019\end{array}$ \\
\hline \multicolumn{13}{|l|}{ Daylight } \\
\hline \multicolumn{13}{|c|}{ Season of blood sampling $\S$ (reference: high sunlight) } \\
\hline $\begin{array}{l}\text { Low sunlight } \\
\text { Global } p \text { value }\end{array}$ & 0.57 & $\begin{array}{l}0.51 \text { to } 0.63 \\
<0.0001\end{array}$ & 0.29 & $\begin{array}{l}0.21 \text { to } 0.36 \\
<0.0001\end{array}$ & -1.03 & $\begin{array}{l}-1.08 \text { to }-0.98 \\
<0.0001\end{array}$ & -0.43 & $\begin{array}{l}-0.49 \text { to }-0.36 \\
<0.0001\end{array}$ & -0.92 & $\begin{array}{l}-0.97 \text { to }-0.87 \\
<0.0001\end{array}$ & -0.36 & $\begin{array}{l}-0.42 \text { to }-0.29 \\
<0.0001\end{array}$ \\
\hline \multicolumn{13}{|c|}{ Latitude (reference: $65^{\circ} \mathrm{N}$ ) } \\
\hline $\begin{array}{l}>65^{\circ} \mathrm{N} \\
\text { Global } p \text { value }\end{array}$ & -0.08 & $\begin{array}{l}-0.16 \text { to }-0.01 \\
0.023\end{array}$ & -0.06 & $\begin{array}{l}-0.13 \text { to } 0.02 \\
0.12\end{array}$ & -0.14 & $\begin{array}{l}-0.21 \text { to }-0.07 \\
0.0002\end{array}$ & -0.18 & $\begin{array}{l}-0.24 \text { to }-0.12 \\
<0.0001\end{array}$ & -0.16 & $\begin{array}{l}-0.23 \text { to }-0.08 \\
<0.0001\end{array}$ & -0.20 & $\begin{array}{l}-0.26 \text { to }-0.13 \\
<0.0001\end{array}$ \\
\hline \multicolumn{13}{|l|}{ Anthropometry } \\
\hline \multicolumn{13}{|c|}{ BMI $\left(\mathrm{kg} / \mathrm{m}^{2}\right)$ (reference : normal (18.5-24.99)) } \\
\hline $\begin{array}{l}\text { Underweight } \\
(<18.5)\end{array}$ & -0.05 & -0.25 to 0.15 & -0.06 & -0.24 to 0.13 & -0.08 & -0.27 to 0.12 & -0.06 & -0.22 to 0.10 & -0.09 & -0.29 to 0.11 & -0.08 & -0.25 to 0.09 \\
\hline $\begin{array}{l}\text { Overweight } \\
(25-29.99)\end{array}$ & -0.10 & -0.17 to -0.04 & -0.01 & -0.08 to 0.06 & 0.02 & -0.04 to 0.08 & -0.001 & -0.06 to 0.06 & -0.004 & -0.07 to 0.06 & -0.005 & -0.07 to 0.06 \\
\hline $\begin{array}{l}\text { Obese }(\geq 30) \\
\text { Global } p \text { value }\end{array}$ & -0.13 & $\begin{array}{l}-0.24 \text { to }-0.03 \\
0.0035\end{array}$ & -0.01 & $\begin{array}{l}-0.14 \text { to } 0.11 \\
0.94\end{array}$ & -0.19 & $\begin{array}{l}-0.30 \text { to }-0.09 \\
0.0008\end{array}$ & -0.16 & $\begin{array}{l}-0.27 \text { to }-0.06 \\
0.0035\end{array}$ & -0.23 & $\begin{array}{l}-0.33 \text { to }-0.12 \\
0.0002\end{array}$ & -0.17 & $\begin{array}{l}-0.27 \text { to }-0.06 \\
0.0057\end{array}$ \\
\hline \multicolumn{13}{|c|}{ Waist circumference $(\mathrm{cm})$ (reference: $\mathrm{m}<94, \mathrm{f}<80$ ) } \\
\hline $\begin{array}{l}M \geq 94, F \geq 80 \\
\text { Global } p \text { value }\end{array}$ & -0.09 & $\begin{array}{l}-0.15 \text { to }-0.03 \\
0.003\end{array}$ & -0.10 & $\begin{array}{l}-0.18 \text { to }-0.02 \\
0.013\end{array}$ & -0.13 & $\begin{array}{l}-0.19 \text { to }-0.07 \\
<0.0001\end{array}$ & -0.05 & $\begin{array}{l}-0.12 \text { to } 0.01 \\
0.11\end{array}$ & -0.15 & $\begin{array}{l}-0.21 \text { to }-0.09 \\
<0.0001\end{array}$ & -0.08 & $\begin{array}{l}-0.15 \text { to }-0.01 \\
0.030\end{array}$ \\
\hline \multicolumn{13}{|c|}{ Socioeconomic position (reference: I+ll (professional)) } \\
\hline III (Skilled worker) & -0.05 & -0.13 to 0.03 & -0.05 & -0.13 to 0.02 & 0.08 & 0.001 to 0.15 & 0.03 & -0.04 to 0.09 & 0.07 & -0.003 to 0.15 & 0.03 & -0.04 to 0.09 \\
\hline $\begin{array}{l}\text { IV (Unskilled } \\
\text { worker) }\end{array}$ & -0.06 & -0.15 to 0.02 & 0.01 & -0.07 to 0.10 & 0.14 & 0.06 to 0.22 & 0.02 & -0.05 to 0.09 & 0.12 & 0.04 to 0.21 & 0.03 & -0.05 to 0.10 \\
\hline V(Farmer) & -0.11 & -0.27 to 0.06 & -0.02 & -0.18 to 0.14 & 0.06 & -0.10 to 0.22 & -0.06 & -0.19 to 0.08 & 0.03 & -0.13 to 0.20 & -0.06 & -0.20 to 0.08 \\
\hline VI(Other) & -0.14 & -0.23 to -0.05 & -0.06 & -0.16 to 0.03 & 0.21 & 0.11 to 0.29 & 0.05 & -0.03 to 0.13 & 0.18 & 0.09 to 0.28 & 0.05 & -0.03 to 0.13 \\
\hline Global $p$ value & & 0.056 & & 0.33 & & 0.0002 & & 0.49 & & 0.0012 & & 0.56 \\
\hline \multicolumn{13}{|l|}{ Lifestyle } \\
\hline \multicolumn{13}{|c|}{ Smoking (reference: non-smoker) } \\
\hline $\begin{array}{l}\text { Formerl } \\
\text { occasional } \\
\text { smoker }\end{array}$ & -0.03 & -0.10 to 0.04 & -0.01 & -0.08 to 0.06 & 0.05 & -0.02 to 0.12 & 0.02 & -0.03 to 0.08 & 0.04 & -0.03 to 0.11 & 0.02 & -0.04 to 0.08 \\
\hline $\begin{array}{l}\text { Active smoker } \\
\text { Global } p \text { value }\end{array}$ & -0.10 & $\begin{array}{l}-0.17 \text { to }-0.03 \\
0.014\end{array}$ & -0.05 & $\begin{array}{l}-0.12 \text { to } 0.02 \\
0.37\end{array}$ & 0.007 & $\begin{array}{l}-0.06 \text { to } 0.07 \\
0.39\end{array}$ & -0.05 & $\begin{array}{l}-0.10 \text { to } 0.01 \\
0.071\end{array}$ & -0.02 & $\begin{array}{l}-0.08 \text { to } 0.05 \\
0.37\end{array}$ & -0.06 & $\begin{array}{l}-0.12 \text { to } 0.0002 \\
0.051\end{array}$ \\
\hline \multicolumn{13}{|c|}{ Alcohol consumption (g/day) (reference: abstainer) } \\
\hline Low risk drinker & 0.04 & -0.06 to 0.14 & 0.07 & -0.03 to 0.16 & 0.17 & 0.07 to 0.27 & 0.12 & 0.04 to 0.20 & 0.19 & 0.09 to 0.29 & 0.14 & 0.06 to 0.23 \\
\hline $\begin{array}{l}\text { At-risk drinker } \\
\text { Global p value }\end{array}$ & 0.03 & $\begin{array}{l}-0.12 \text { to } 0.18 \\
0.71\end{array}$ & 0.07 & $\begin{array}{l}-0.08 \text { to } 0.21 \\
0.39\end{array}$ & 0.13 & $\begin{array}{l}-0.02 \text { to } 0.28 \\
0.0043\end{array}$ & 0.19 & $\begin{array}{l}0.06 \text { to } 0.31 \\
0.0041\end{array}$ & 0.14 & $\begin{array}{l}-0.02 \text { to } 0.29 \\
0.0012\end{array}$ & 0.20 & $\begin{array}{l}0.07 \text { to } 0.33 \\
0.0019\end{array}$ \\
\hline
\end{tabular}


Table 3 Continued

\begin{tabular}{|c|c|c|c|c|c|c|c|c|c|c|c|c|}
\hline \multirow{3}{*}{$\begin{array}{l}\text { Explanatory } \\
\text { variables }\end{array}$} & \multicolumn{4}{|c|}{ Serum 25(OH)D $\mathrm{D}_{2}, \mathrm{nmol} / \mathrm{L} \dagger$} & \multicolumn{4}{|c|}{ Serum $25(\mathrm{OH}) \mathrm{D}_{3}, \mathrm{nmol} / \mathrm{L} \dagger$} & \multicolumn{4}{|c|}{ Serum 25(OH)D, nmol/L† } \\
\hline & \multicolumn{2}{|c|}{ Univariable } & \multicolumn{2}{|c|}{ Multivariable $\ddagger$} & \multicolumn{2}{|c|}{ Univariable } & \multicolumn{2}{|c|}{ Multivariable $\ddagger$} & \multicolumn{2}{|c|}{ Univariable } & \multicolumn{2}{|c|}{ Multivariable $\ddagger$} \\
\hline & $\mathbf{B}$ & $95 \% \mathrm{Cl}$ & $\bar{\beta}$ & $95 \% \mathrm{Cl}$ & $\bar{\beta}$ & $95 \% \mathrm{Cl}$ & $\bar{\beta}$ & $95 \% \mathrm{Cl}$ & $\bar{\beta}$ & $95 \% \mathrm{Cl}$ & $\bar{\beta}$ & $95 \% \mathrm{Cl}$ \\
\hline \multicolumn{13}{|c|}{ Leisure time computer use (reference : never) } \\
\hline $\begin{array}{l}\text { No more than } \\
\text { once per week }\end{array}$ & 0.03 & -0.06 to 0.12 & 0.002 & -0.08 to 0.09 & 0.01 & -0.08 to 0.09 & 0.02 & -0.05 to 0.09 & 0.01 & -0.08 to 0.10 & 0.02 & -0.06 to 0.09 \\
\hline $\begin{array}{l}\text { On } 2 \text { to } 5 \text { days } \\
\text { per week }\end{array}$ & 0.03 & -0.04 to 0.10 & -0.01 & -0.08 to 0.06 & -0.04 & -0.11 to 0.03 & -0.03 & -0.09 to 0.03 & -0.03 & -0.10 to 0.04 & -0.03 & -0.09 to 0.03 \\
\hline $\begin{array}{l}\text { On more than } \\
5 \text { days per week }\end{array}$ & 0.09 & 0.01 to 0.17 & 0.02 & -0.07 to 0.10 & -0.20 & -0.28 to -0.12 & -0.09 & -0.16 to -0.02 & -0.17 & -0.25 to -0.10 & -0.08 & -0.15 to -0.01 \\
\hline Global $p$ value & & 0.14 & & 0.93 & & $<0.0001$ & & 0.026 & & $<0.0001$ & & 0.10 \\
\hline \multicolumn{13}{|c|}{ Quartile of physical activity (MET-hours per week) (reference: QI: 0.0-3.79) } \\
\hline QII: $3.80-11.29$ & 0.08 & 0.0003 to 0.16 & 0.05 & -0.03 to 0.12 & -0.02 & -0.10 to 0.06 & 0.003 & -0.06 to 0.07 & -0.01 & -0.09 to 0.07 & 0.01 & -0.06 to 0.07 \\
\hline QIII: 11.30-21.99 & 0.10 & 0.02 to 0.18 & 0.05 & -0.03 to 0.12 & 0.02 & -0.06 to 0.10 & 0.05 & -0.01 to 0.12 & 0.04 & -0.04 to 0.12 & 0.07 & -0.002 to 0.13 \\
\hline $\begin{array}{l}\text { QIV: >22.0 } \\
\text { Global } p \text { value }\end{array}$ & 0.11 & $\begin{array}{l}0.03 \text { to } 0.20 \\
0.022\end{array}$ & 0.08 & $\begin{array}{l}-0.002 \text { to } 0.16 \\
0.29\end{array}$ & 0.15 & $\begin{array}{l}0.07 \text { to } 0.23 \\
<0.0001\end{array}$ & 0.14 & $\begin{array}{l}0.07 \text { to } 0.20 \\
<0.0001\end{array}$ & 0.18 & $\begin{array}{l}0.10 \text { to } 0.26 \\
<0.0001\end{array}$ & 0.16 & $\begin{array}{l}0.09 \text { to } 0.23 \\
<0.0001\end{array}$ \\
\hline \multicolumn{13}{|c|}{ Diet score (reference: healthy diet) } \\
\hline Unhealthy diet & -0.12 & -0.21 to -0.03 & -0.06 & -0.15 to 0.02 & -0.07 & -0.15 to 0.02 & -0.07 & $\begin{array}{l}-0.15 \text { to } \\
-0.0004\end{array}$ & -0.10 & -0.18 to -0.01 & -0.09 & -0.17 to -0.01 \\
\hline Global $p$ value & & 0.009 & & 0.14 & & 0.15 & & 0.049 & & 0.034 & & 0.022 \\
\hline
\end{tabular}

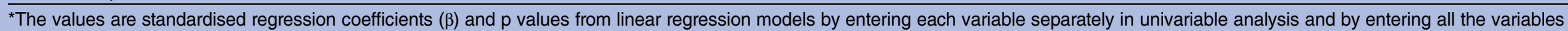
in multivariable analysis.

$\dagger 1 \mathrm{SD}$ increase/decrease in $25(\mathrm{OH}) \mathrm{D}_{2}, 25(\mathrm{OH}) \mathrm{D}_{3}$ and $25(\mathrm{OH}) \mathrm{D} \mathrm{nmol} / \mathrm{L}$ per 1 unit or category change in explanatory variable.

$\ddagger$ Analysis performed on $\mathrm{N}=3996$ (total). Blood drawn only in winter on $\mathrm{N}=343$ men and $\mathrm{N}=419$ in women residing in Helsinki were excluded.

$\S$ The season of blood sampling were categorised as high sunlight (summer (1 June-30 August), autumn (1 September-31 October)) and low sunlight (winter (1 November-31 March) and

spring (1 April-31 May)).

MET, metabolic equivalent of task of physical activity; $25(\mathrm{OH}) \mathrm{D}$, 25-hydroxyvitamin $\mathrm{D} ; 25(\mathrm{OH}) \mathrm{D}_{2}$, ergocalciferol; $25(\mathrm{OH}) \mathrm{D}_{3}$, cholecalciferol. 
$(\mathrm{OH}) \mathrm{D}_{3}$ concentrations of $0.17 \mathrm{nmol} / \mathrm{L}$ and $0.48 \mathrm{nmol} /$ $\mathrm{L}$, respectively.

Total $25(\mathrm{OH}) \mathrm{D}$ associations with potential determinants reflect similar associations as reported for $25(\mathrm{OH})$ $\mathrm{D}_{3}$ concentrations, with the exception of waist circumference and leisure time computer use (table 3). OCP users (vs non-users) were associated with a $0.50 \mathrm{nmol} / \mathrm{L}$ greater serum $25(\mathrm{OH}) \mathrm{D}$ concentration.

\section{DISCUSSION}

According to the present data collected in 1997, 28\% of young adults in Northern Finland were exposed to the risk of vitamin D insufficiency defined by IOM. The average vitamin $\mathrm{D}$ status observed in our study was higher than those reported by other studies from the same geographical location (ie, Finland, ${ }^{27}{ }^{28}$ ), despite these latter samples being collected after 2002, that is, year of the first Finnish fortification campaign for vitamin $\mathrm{D}$. The mean concentration of serum $25(\mathrm{OH}) \mathrm{D}$ measured in both precited studies of the same geographical location (mean age: approx. 37 and 60 years) were nearly $10 \mathrm{nmol} / \mathrm{L}$ lower when compared with our population. Our present sample can be considered as a good representation of the young adult population living in Finland at the time of measurement. ${ }^{29}$ In comparison with previous findings, our data may also raise queries about the efficacy of the first wave of fortification introduced in Finland in the year 2002. ${ }^{8}$ The fortification levels were since increased in $2010 .^{8}$ Careful consideration should be made before speculating a potential causation. We must acknowledge, for instance, the differences in study design such as analysis of wider age groups and determination of vitamin $\mathrm{D}$ status by radioimmunoassay as opposed to mass spectrometry.

Adding to previous literature, we observed a strong impact of the duration of sunlight in determining the vitamin D status irrespective of the gender. ${ }^{27} 3031$ The latitude of residence also plays an important role in determining vitamin $\mathrm{D}$ status. During the six long winter months in northern latitudes $\left(>60^{\circ} \mathrm{N}\right)$, the few hours of daylight are incapable of increasing vitamin D naturally. ${ }^{6}$ The usage of computers outside working hours and a reduced level of physical activity were negatively associated with vitamin D status, which supports previous reports. ${ }^{30-33}$ It is suspected that the observed association between the characteristics of sedentary behaviour in young adults and a lower vitamin $\mathrm{D}$ status is likely to be explained by significant changes in the time spent outdoors. ${ }^{30} 3233$ Unfortunately, the current study does not distinguish between indoor and outdoor physical activity that would help to ascertain this hypothesis. In addition, our results supported the negative association between vitamin $\mathrm{D}$ status and obesity or higher waist circumference. ${ }^{1} 273233$ The current hypotheses linking obesity and reduced vitamin $\mathrm{D}$ status consider either an effect due to an increased capacity of storage of vitamin $\mathrm{D}$ in the fat tissue or the interplay with autocrine factors produced by the adipose tissues. ${ }^{2}{ }^{34}$ The experimental evidence from animal and human studies is suggesting a direct biological pathway, although the question of reverse causality has not been fully addressed. ${ }^{1}{ }^{2}$ Currently, the epidemiological data in adults is supporting a causal inference of increased BMI in the reduction of vitamin $\mathrm{D}$ status while the reverse has not been confirmed. ${ }^{1}$ In addition, unhealthy diet was negatively associated with vitamin D status. Unfortunately, the food questionnaire used in the present study could not discriminate precisely the consumption of fatty fish or mushrooms to account for a precise dietary quantity of vitamin D3 and D2, respectively. Diet score has been previously examined in the same sample as an adequate proxy of a healthy or unhealthy diet, ${ }^{23}$ but future research with precise food frequency questionnaire is warranted. This will help understand the role of the natural source of dietary vitamin $\mathrm{D}$ to reinforce maintenance of a healthy dietary intake whenever possible.

Many reports and reviews consider vitamin D status as a mere representation of individual lifestyle and health behaviour. ${ }^{35}$ The positive association between vitamin $\mathrm{D}$ status and the use of OCP is in contrast with the suggestion that vitamin $\mathrm{D}$ status merely bio-marks a healthy status. In fact, OCP was linked to $10 \%$ higher vitamin D status as consistently reported. ${ }^{36}{ }^{37}$ Similarly, one study which examined the effect of hormonal contraceptives during vitamin D supplementation in premenopausal women reported that the use of exogenous oestrogen would enhance the response to supplementation. ${ }^{38}$ It is not apparent what the underlying mechanism is pertaining to a higher vitamin D status in women using OCP. Two hypotheses are currently being examined to understand such association. These examine whether the mechanisms by which oestrogen increases the $25(\mathrm{OH}) \mathrm{D}$ are due to higher activity of vitamin D 25-hydroxylase in the liver, ${ }^{39}$ or an increase in circulating concentration of vitamin D binding protein (DBP). ${ }^{37}$ According to the IOM classification, OCP users in our study are more likely to be classified as vitamin D sufficient. Previous research using the same data has shown a link between the use of OCP and inflammation. ${ }^{26}$ It will therefore be essential to analyse the pathways underpinning the role of OCP in simultaneously increasing inflammation and vitamin $\mathrm{D}$ status. Based on evidence from this and other studies reporting consistently higher vitamin D status in women using OCP, it may be important to implement a corrective factor to the IOM criteria to avoid overestimation of vitamin D status in this subgroup of women.

\section{Importance of considering D3 and D2 isoforms}

Public health recommendations and clinical diagnostics do not currently distinguish between vitamin D2 and D3. ${ }^{10}$ However, there is disagreement on whether these two forms should be considered equivalent. ${ }^{10}{ }^{40}$ Additionally, $25(\mathrm{OH}) \mathrm{D}_{3}$ accounted for the vast majority $(>90 \%)$ of the circulating $25(\mathrm{OH}) \mathrm{D}$ concentrations in the present population. Our study and the study 
performed by Tolppanen $e t a l^{1}$ were in agreement on the reported associations between the season of blood sampling and the concentrations in $25(\mathrm{OH}) \mathrm{D}_{2}$ and 25 $(\mathrm{OH}) \mathrm{D}_{3}$. The determinants associated with the vitamin D status also influenced the serum concentrations of 25 $(\mathrm{OH}) \mathrm{D}_{3}$, with the highest effect being exerted by the season. Importantly, we replicated the associations of the seasonal variation but not the SEP as first observed in children (mean age 9.8 years) of the Avon Longitudinal Studies of Parents and Children. ${ }^{31}$ As expected, 25(OH) $\mathrm{D}_{3}$, known as the main contributor of vitamin $\mathrm{D}$ status obtained from sunlight, was positively associated with the season of blood sampling and latitude of residence. Interestingly, we observed a heightened vitamin $25(\mathrm{OH})$ $\mathrm{D}_{2}$ status during the winter months that has yet to be understood. However, we do not have information on supplement use which hinders the ability to assess the increased vitamin $25(\mathrm{OH}) \mathrm{D}_{2}$ status during winter. As suggested by Tolppanen and colleagues, if serum vitamin D2 is largely associated with dietary and some socioeconomic related factors, this may provide an indication of compensatory behaviour which can be adopted to correct the vitamin D status during the low sunlight months. ${ }^{31}$

\section{CONCLUSIONS AND IMPLICATIONS}

Our results have provided information on the potential determinants associated with the vitamin $\mathrm{D}$ status prior to the implementation of a nationwide fortification policy. Understanding the associations between sex, season, latitude and multiple lifestyle factors with dual sources of vitamin $\mathrm{D}\left(25(\mathrm{OH}) \mathrm{D}_{2}\right.$ and $\left.25(\mathrm{OH}) \mathrm{D}_{3}\right)$ will help better understand the role of vitamin $\mathrm{D}$ in research, clinical and public health implications. The data also supported a differential association of $25(\mathrm{OH}) \mathrm{D}_{2}$ and 25 $(\mathrm{OH}) \mathrm{D}_{3}$ concentrations with sunlight which might have an impact on future strategy for supplementation. These differential results also question current strategies of vitamin D supplementation and IOM cutoffs for vitamin D sufficiency and warrant a personalised approach, accounting for individual and lifestyle characteristics. The fortification of fluid milk products $(0.5 \mu \mathrm{g} / 100 \mathrm{~g})$ was introduced in Finland in 2002 with limited efficiency in all age groups. ${ }^{8}$ More recently, in April 2010, the fortification levels have been raised further $(1.0 \mu \mathrm{g} / 100 \mathrm{~g}) .^{8}$ In addition, in 2012, the Nordic and Finnish nutritional experts have recommended $10 \mu \mathrm{g} /$ day for all individuals aged 6 months to 75 years, in addition to dietary intake. ${ }^{41}$ Our intended follow-up study from NFBC1966 at 46 years, ${ }^{42}$ will be helpful in measuring the efficiency of waves of fortification before (1997) and after (2012), taking into account multiple determinants and personal supplement use in Northern Finland.

\footnotetext{
Author affiliations

${ }^{1}$ Biocenter Oulu, University of Oulu, Oulu, Finland

${ }^{2}$ Faculty of Medicine, Center for Life Course Health Research, University of Oulu, Oulu, Finland
}

${ }^{3}$ Centre for Population Health Research, School of Health Sciences and Sansom Institute, University of South Australia, South Australian Health and Medical Research Institute, Adelaide, Australia

${ }^{4}$ Population, Policy and Practice, Institute of Child Health, University College London, London, UK

${ }^{5}$ Department of Medical Epidemiology and Biostatistics, Karolinska Institutet, Stockholm, Sweden

${ }^{6} \mathrm{MRC}$ and Unit of Primary Care, Oulu University Hospital, Oulu, Finland

${ }^{7}$ Department of Physiology, Institute of Biomedicine, University of Oulu, Oulu, Finland

${ }^{8}$ Department of Gastroenterology and Metabolism, Poznan University of Medical Sciences, Poznan, Poland

${ }^{9} \mathrm{CEU}$ Cardenal Herrera University, Valencia, Spain

${ }^{10}$ Department of Epidemiology and Biostatistics, School of Public health, Imperial College London, London, UK

${ }^{11}$ MRC-PHE Centre for Environment and Health, School of Public Health, Imperial College London, London, UK

${ }^{12}$ Department of Genomics of Complex Diseases, School of Public Health, Imperial College London, London, UK

\section{Twitter Follow Saranya Palaniswamy @saranbio}

Acknowledgements We thank the entire NFBC1966 study team, including the research staff and all others involved in the data collection and processing and those involved in the oversight and management of the study. We acknowledge late Professor Paula Rantakallio for launch of Northern Finland Birth Cohort 1966 and initial data collection, Sarianna Vaara for data collection, Markku Koiranen for data management and Tuula Ylitalo for administration. The authors thank all the participants of NFBC1966 study.

Contributors SP, MRJ and SS designed the analysis plan. SP conducted the analysis and wrote the manuscript with guidance from SS, JJ, DMW and MRJ. EH and MRJ were responsible for data collection of variables and blood sampling related to this analysis. EL reviewed/edited the manuscript. All authors contributed intellectually to the manuscript and approved the final version.

Funding This work was financially supported by the Academy of Finland (MRJ, grant number 24300796); Medical Research Council, UK (EH, grant number G0601653); Biocenter Oulu Doctoral Programme (SP); European Union's Horizon 2020 research and innovation programme (MRJ, SS, DMW, grant number 633595) for the DynaHEALTH action.

Disclaimer The funders had no role in the design, analysis or writing of this article.

Competing interests None declared.

\section{Patient consent Obtained.}

Ethics approval The study was approved by the ethical committee of University of Oulu and Northern Ostrobothnia Hospital District. The procedures follow the 1964 Helsinki declaration and its later amendments or comparable ethical standards.

Provenance and peer review Not commissioned; externally peer reviewed.

Data sharing statement Data are available on request to the NFBC1966 Data Sharing Committee. NFBC1966 data sharing policies and processes meet the requirement and expectations of Northern Ostrobothnia Hospital district policy on sharing of data from population and patient cohorts. Data requests should be submitted to Minna.Mannikko@oulu.fi; further details can be found at http://www.oulu.fi/nfbc/. These policies and processes are in places to ensure the use of data from this prospective birth cohort study is within the bounds of consent given previously by study members, complies with Northern Ostrobothnia Hospital district guidance on ethics and research governance and meets rigorous University of Oulu data security standards.

Open Access This is an Open Access article distributed in accordance with the terms of the Creative Commons Attribution (CC BY 4.0) license, which permits others to distribute, remix, adapt and build upon this work, for commercial use, provided the original work is properly cited. See: http:// creativecommons.org/licenses/by/4.0/ 


\section{REFERENCES}

1. Vimaleswaran KS, Berry DJ, Lu C, et al. Causal relationship between obesity and vitamin D status: bi-directional Mendelian randomization analysis of multiple cohorts. PLoS Med 2013;10: e1001383.

2. Mutt SJ, Karhu T, Lehtonen S, et al. Inhibition of cytokine secretion from adipocytes by 1,25-dihydroxyvitamin D3via the NF-kB pathway. FASEB J 2012;26:4400-7.

3. Pham TM, Ekwaru JP, Loehr SA, et al. The relationship of serum 25-hydroxyvitamin $\mathrm{D}$ and insulin resistance among nondiabetic Canadians: a longitudinal analysis of participants of a preventive health program. PLOS ONE 2015;10:e0141081.

4. Afzal S, Brøndum-Jacobsen P, Bojesen SE, et al. Genetically low vitamin $D$ concentrations and increased mortality: Mendelian randomisation analysis in three large cohorts. BMJ 2014; 349:g6330.

5. Hossein-nezhad A, Holick MF. Vitamin D for health: a global perspective. Mayo Clin Proc 2013;88:720-55.

6. Huotari A, Herzig KH. Vitamin D and living in northern latitudes-an endemic risk area for vitamin $\mathrm{D}$ deficiency. Int J Circumpolar Health 2008;67:164-78.

7. Holick MF. Vitamin D deficiency. N Engl J Med 2007;357:266-81.

8. Itkonen ST, Lamberg-Allardt C. Food fortification as a means to increase vitamin D intake. Br J Nutr 2016;115:2075-6.

9. Lamberg-Allardt $\mathrm{C}$, Brustad M, Meyer HE, et al. Vitamin D-a systematic literature review for the 5 th edition of the Nordic Nutrition Recommendations. Food Nutr Res 2013;57:22671.

10. Mazahery $\mathrm{H}$, von Hurst PR. Factors affecting 25-hydroxyvitamin D concentration in response to vitamin D supplementation. Nutrients 2015;7:5111-42.

11. Jungert A, Neuhauser-Berthold M. Sex-specific determinants of serum 25-hydroxyvitamin D3 concentrations in an elderly German cohort: a cross-sectional study. Nutr Metab (Lond) 2015;12:2.

12. Sohl E, Heymans MW, de Jongh RT, et al. Prediction of vitamin D deficiency by simple patient characteristics. Am J Clin Nutr 2014:99:1089-95.

13. Nevill AM, Metsios GS. The need to redefine age- and gender-specific overweight and obese body mass index cutoff points. Nutr Diabetes 2015;5:e186.

14. Tylavsky FA, Cheng S, Lyytikainen A, et al. Strategies to improve vitamin $D$ status in northern European children: exploring the merits of vitamin D fortification and supplementation. J Nutr 2006;136:1130-4.

15. Rantakallio P. Groups at risk in low birth weight infants and perinatal mortality. Acta Paediatr Scand 1969;193(Suppl 193):1+.

16. Rantakallio $P$. The longitudinal study of the northern Finland birth cohort of 1966. Paediatr Perinat Epidemiol 1988;2:59-88.

17. Jarvelin MR, Sovio U, King V, et al. Early life factors and blood pressure at age 31 years in the 1966 northern Finland birth cohort. Hypertension 2004;44:838-46.

18. Williams DM, Palaniswamy S, Sebert S, et al. 25-hydroxyvitamin D concentration and leukocyte telomere length in young adults: findings from the Northern Finland birth cohort 1966. Am J Epidemiol 2016;183:191-8.

19. IOM (Institute of Medicine). Dietary reference intakes for calcium and vitamin D. Washington DC: The National Academic Press, 2011.

20. Finnish Meteorological Institute. Seasons in Finland. 2016. http://en. ilmatieteenlaitos.fi/seasons-in-finland (accessed 5 Jun 2016).

21. Obesity: preventing and managing the global epidemic. Report of a WHO consultation. World Health Organ Tech Rep Ser 2000;894:i, xii, 1-253.

22. Alberti KG, Eckel RH, Grundy SM, et al. Harmonizing the metabolic syndrome: a joint interim statement of the International Diabetes Federation Task Force on Epidemiology and Prevention; National Heart, Lung, and Blood Institute; American Heart Association; World Heart Federation; International Atherosclerosis Society; and
International Association for the Study of Obesity. Circulation 2009;120:1640-5.

23. Laitinen J, Pietiläinen $\mathrm{K}$, Wadsworth $\mathrm{M}$, et al. Predictors of abdominal obesity among 31-y-old men and women born in Northern Finland in 1966. Eur J Clin Nutr 2004:58:180-90.

24. Fawehinmi TO, llomäki J, Voutilainen S, et al. Alcohol consumption and dietary patterns: the FinDrink study. PLOS ONE 2012;7:e38607.

25. Suija K, Timonen M, Suviola M, et al. The association between physical fitness and depressive symptoms among young adults: results of the Northern Finland 1966 birth cohort study. BMC Public Health 2013;13:535, 2458-13-535.

26. Morin-Papunen L, Martikainen H, McCarthy MI, et al. Comparison of metabolic and inflammatory outcomes in women who used oral contraceptives and the levonorgestrel-releasing intrauterine device in a general population. Am J Obstet Gynecol 2008;199:529.e1-e10.

27. Voipio AJ, Pahkala KA, Viikari JS, et al. Determinants of serum 25 $(\mathrm{OH}) \mathrm{D}$ concentration in young and middle-aged adults. The Cardiovascular Risk in Young Finns Study. Ann Med2015;47:253-62.

28. Miettinen ME, Kinnunen L, Leiviskä J, et al. Association of serum 25-hydroxyvitamin D with lifestyle factors and metabolic and cardiovascular disease markers: population-based cross-sectional study (FIN-D2D). PLOS ONE 2014;9:e100235.

29. Statistics of Finland, National Institute for Health and Welfare. Obesity. 2016. http://findikaattori.fi/en/62 (accessed 13 October 2016).

30. Hypponen E, Power C. Hypovitaminosis D in British adults at age 45 y: nationwide cohort study of dietary and lifestyle predictors. $A m$ J Clin Nutr 2007;85:860-8.

31. Tolppanen AM, Fraser A, Fraser WD, et al. Risk factors for variation in 25-hydroxyvitamin $\mathrm{D}(3)$ and $\mathrm{D}(2)$ concentrations and vitamin $\mathrm{D}$ deficiency in children. J Clin Endocrinol Metab 2012;97:1202-10.

32. Jääskelainen $T$, Knekt $P$, Marniemi $J$, et al. Vitamin D status is associated with sociodemographic factors, lifestyle and metabolic health. Eur J Nutr 2013:52:513-25.

33. Skaaby $\mathrm{T}$, Husemoen LL, Thuesen $\mathrm{BH}$, et al. Longitudinal associations between lifestyle and vitamin D: a general population study with repeated vitamin D measurements. Endocrine 2016;51:342-50.

34. Mutt SJ, Hyppönen E, Saarnio J, et al. Vitamin D and adipose tissue-more than storage. Front Physiol 2014;5:228.

35. Mangin M, Sinha R, Fincher K. Inflammation and vitamin D: the infection connection. Inflamm Res 2014:63:803-19.

36. Harris SS, Dawson-Hughes B. The association of oral contraceptive use with plasma 25-hydroxyvitamin D levels. J Am Coll Nutr 1998;17:282-4.

37. Møller UK, Streym Sv, Jensen LT, et al. Increased plasma concentrations of vitamin D metabolites and vitamin D binding protein in women using hormonal contraceptives: a cross-sectional study. Nutrients 2013;5:3470-80.

38. Nelson ML, Blum JM, Hollis BW, et al. Supplements of 20 microg/d cholecalciferol optimized serum 25-hydroxyvitamin D concentrations in 80\% of premenopausal women in winter. J Nutr 2009;139:540-6.

39. Saarem K, Pedersen JI. Sex differences in the hydroxylation of cholecalciferol and of 5 beta-cholestane-3 alpha, 7 alpha, 12 alpha-triol in rat liver. Biochem $J$ 1987;247:73-8.

40. Tripkovic L, Lambert H, Hart K, et al. Comparison of vitamin D2 and vitamin D3 supplementation in raising serum 25-hydroxyvitamin D status: a systematic review and meta-analysis. Am J Clin Nutr 2012;95:1357-64.

41. Nordic Council of Ministers. Nordic nutrition recommendations 2012 Integrating nutrition and physical activity, 5th edn. Copenhagen: Nordic Council of Ministers, 2014.

42. Larsen SC, Ängquist L, Moldovan M, et al. Serum 25-hydroxyvitamin $D$ status and longitudinal changes in weight and waist circumference: influence of genetic predisposition to adiposity. PLoS ONE 2016;11:e0153611. 